\title{
サファイア隔膜真空計の開発と製品の特長
}

\author{
吉 川 康 秀*1
}

\section{Development of Sapphire Based Capacitance Vacuum Gauge and Feature of Product Yasuhide YOSHIKAWA*1}

${ }^{* 1} \mathrm{CP}$ Development Department of Advanced Automation Company of Azbil Corporation, 1-12-2 Kawana, Fujisawa-shi, Kanagawa, 251-8522, Japan

(Received July 6, 2016, Accepted August 1, 2016)

\begin{abstract}
Using single-crystal sapphire as the sensor material, we have developed the Sapphire Capacitance Diaphragm Gauge, which is highprecision, highly-reliable, and intended to be used mainly in semiconductor manufacturing processes. Single-crystal sapphire possesses extremely high corrosion resistance and heat resistance, and also possesses excellent mechanical characteristics. The gauge provides high precision even in harsh environments such as corrosive atmospheres or high temperatures, allowing us to succeed in realizing a long-term stable vacuum measurement. We have also developed high-precision measurement with high linearity and high tolerance for temperature changes, by means of signal processing using microprocessor based control.
\end{abstract}

\section{1. はじめに}

産業界の様々な生産工程において真空を用いた加工処理が 使用されている.なかでも電子デバイスの半導体製造工程で は薄膜形成やエッチングのために多様化された真空プロセス が使用されて抢り, プロセスの真空度が品質に影響するため 精密な圧力計測が要求される. その電子デバイス製造装置内 の圧力計測に使用されるのが隔膜真空計である. 半導体製造 工程は日々進化して抢り, より高い耐食性と耐熱性が要求さ れる苛酷な環境での正確な真空計測が必要になってきてい る. そのため当社では独自に耐食性, 耐熱性に優れた人工サ ファイアを用いたデバイスの実現を目指し, サファイア微細 加工技術開発に取り組み, サファイア隔膜真空計の商品化に 成功したので紹介する1).

\section{2. サファイア隔膜真空計の概要}

主な仕様を以下に記す。

圧力レンジ : 0-13.332 $\mathrm{Pa}$ abs〜0-133.32 kPa abs 自己加熱温度 : 自己加熱なしおよび $45^{\circ} \mathrm{C} \sim 280^{\circ} \mathrm{C}$ 精度 : $0.25 \%$ Reading 0.5\% Reading

Fig. 1 に開発した製品の外観を示す.

\section{3. サファイアセンサチップ及びパッケージ構造}

一般的にサファイアといえば, 宝石の“ブルーサファイア” が良く知られているが，これは不純物が含まれることにより 自然界の中で生成されたものである. 当社がセンサチップに 採用したのは，人工的に製造された不純物を含まない酸化ア ルミニウム $\left(\mathrm{Al}_{2} \mathrm{O}_{3}\right)$ の単結晶である無色透明のサファイア である. サファイアは耐酸性, 耐アルカリ性に優れ, 高温使 用にも耐えられる優れた材料であり, シリコンと同様に単結 晶であることから機械的特性にも優れており, 過酷な環境で

*1 アズビル株式会社 アドバンストオートメーションカンパニー CP 開発部（干251-8522 神奈川県藤沢市川名 1-12-2）

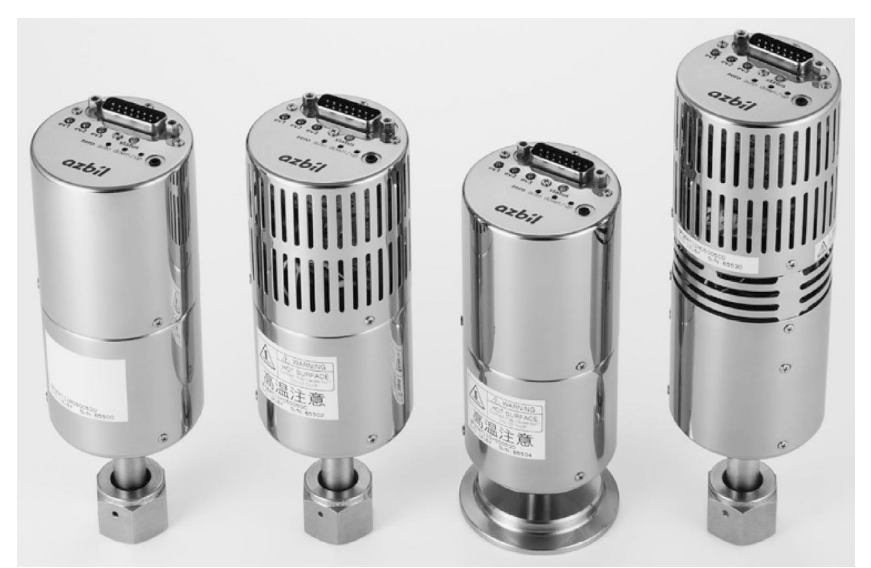

Fig. 1 Products overview.

使用される圧力センサには最適な材料である.

しかしながら丈夫である材料ということは，その反面加工 することが非常に難しい材料であることを意味する．そのた め圧力センサとして実用化することは困難であった．しかし 当社ではサファイアをエッチングする技術や，耐食性や耐熱 性を落とさずにサファイア同土，およびサファイアと金属を 直接接合する技術を開発することに成功した．そのため実用 レベルの製品を開発することができた.

\section{1 サファイアセンサチップ}

Fig. 2 にサファイアセンサチップの外観を，Fig. 3 にそ の模式断面図を示す. 圧力の検出方式は静電容量式である. サファイアセンサ素子は, 圧力に応じて撓み変形するダイア フラムとコンデンサを形成するためのキャビティを有する台 座部からなり，どちらもサファイアを構成材料としている. キャビティはドライエッチングで形成され，ダィアフラムと 台座部はサファイア同士の直接接合で接合されている. Fig. 4 にサファイア同士の接合部の透過型電子顕微鏡（TEM） 像を示す．界面の区別がつかないほどきれいに接合されてい ることがわかる，これにより耐食性, 耐熱性を落とさない接 合が実現できている．ダイアフラムと台座部には対向電極に 


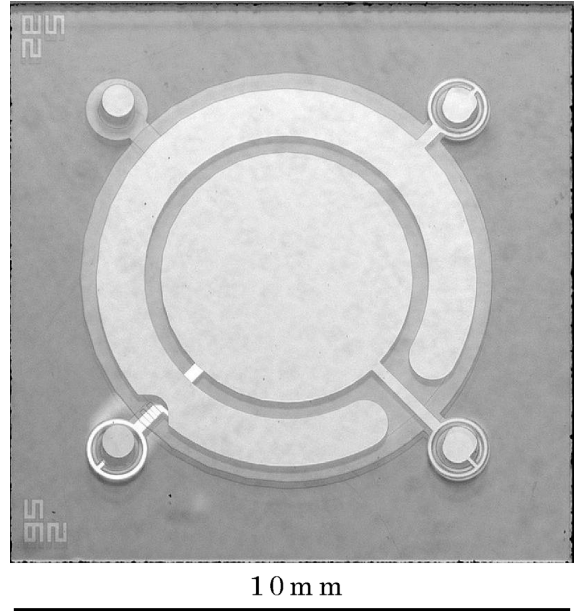

Fig. 2 Sapphire sensor chip.

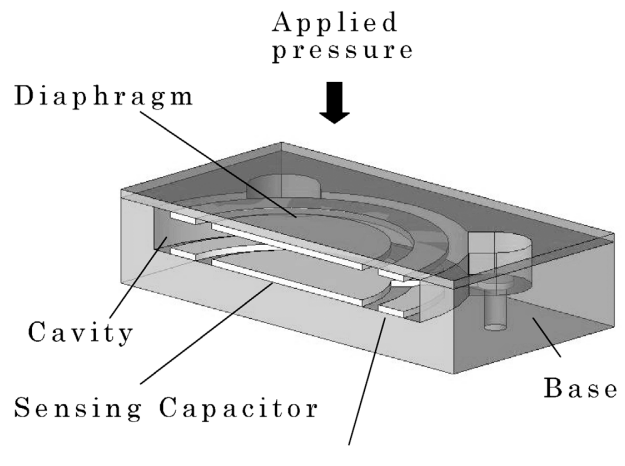

Reference Capacitor

Fig. 3 Cross section of sensor chip.

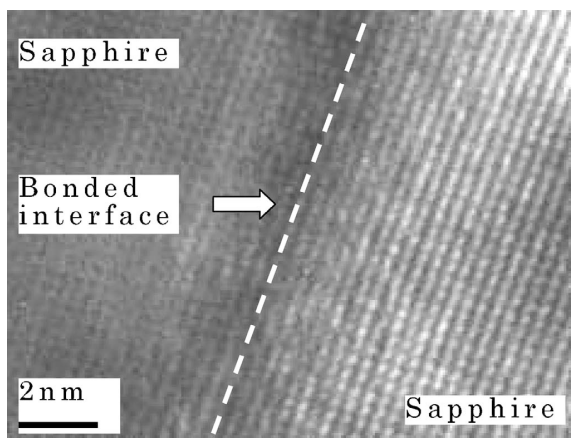

Fig. 4 TEM image of sapphire direct bonding.

よって 2 つキャパシタが構成されている。一つはダイア フラムの中央に位置し圧力によるダイアフラムの変化に応じ て静電容量が変化する感圧キャパシタ, もう一つはダイアフ ラムの端に位置している参照キャパシタである. 感圧キャパ シタと参照キャパシタの両方を計測し演算することにより誤 差の少ない圧力計測が実現できる2．

\section{2 パッケージ構造}

Fig. 5 にパッケージ構造の模式断面図を示す。センサチ ップは機械的ストレスを軽減するため，一旦チップと同じ材 料のサファイア円板で受けて，さらにその円板を金属薄板を 介して金属筐体に接続している。サファイアセンサチップは

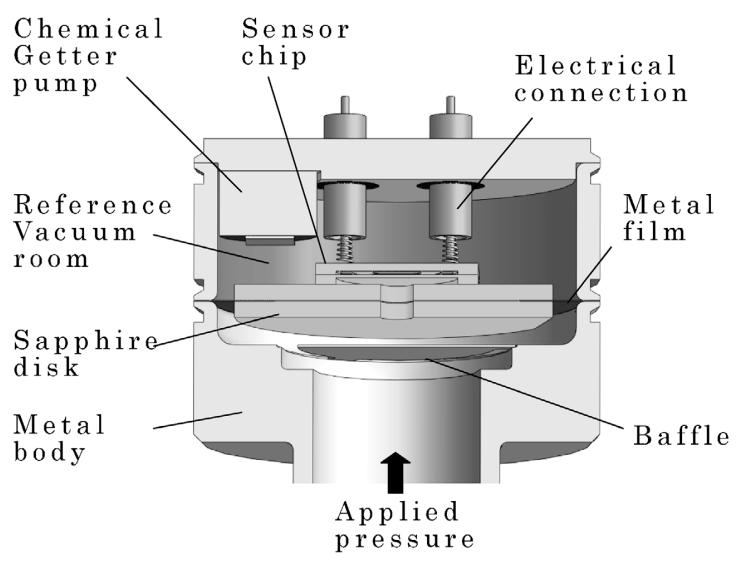

Fig. 5 Cross section of package.

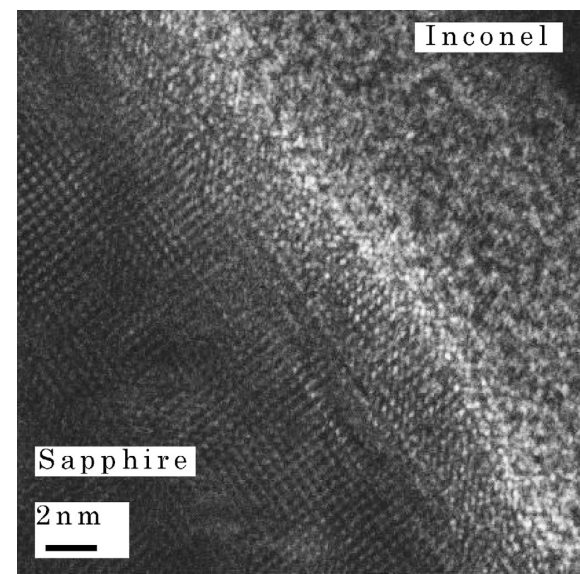

Fig. 6 TEM image of Sapphire to metal bonding.

高い耐食性が実現できているがパッケージで耐食性が悪くな ると製品としては意味がない。よって当社ではサファイアと 金属の介在物のない接合技術を開発した．Fig. 6 にその接 合部の透過型電子顕微鏡（TEM）像を示す．界面の各々の 材料がきれいに拡散されて接合されていることがわかる．こ れにより耐食性，耐熱性を落とさない接合が実現できてい $ろ^{3)}$.

\section{3 検出回路}

開発したセンサチップはフルスケール圧力印加によって $1 \mathrm{pF}$ 程度の微小容量変化しか発生しない。よって製品要求 性能を満たすためには $0.1 \mathrm{fF}$ 以内の容量変化を正確に計測 する回路が必要となる．またセンサはヒータにより高温に加 熱されているため, 検出回路をセンサ近傍には配置できな い.そのためセンサと回路の距離が離れた状態でノイズや寄 生容量の影響を受けずにそれを実現する必要がある.

Fig. 7 に検出回路ブロック図を示す。センサから出力さ れる信号に対してアナログ回路でノイズ成分や寄生容量の影 響をキャンセルし，その出力を $\mathrm{A} / \mathrm{D}$ コンバータでデジタル 信号に変換しマイクロプロセッサに入力している．マイクロ プロセッサでは多項式演算により温度補正や直線性補正を実 施することにより高精度を実現している。 


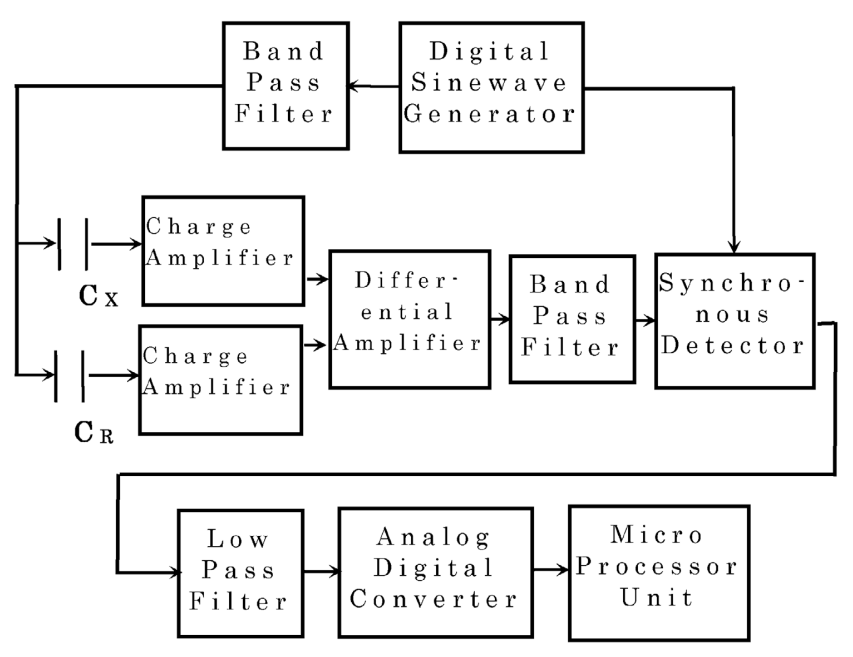

Fig. 7 Circuit block diagram.

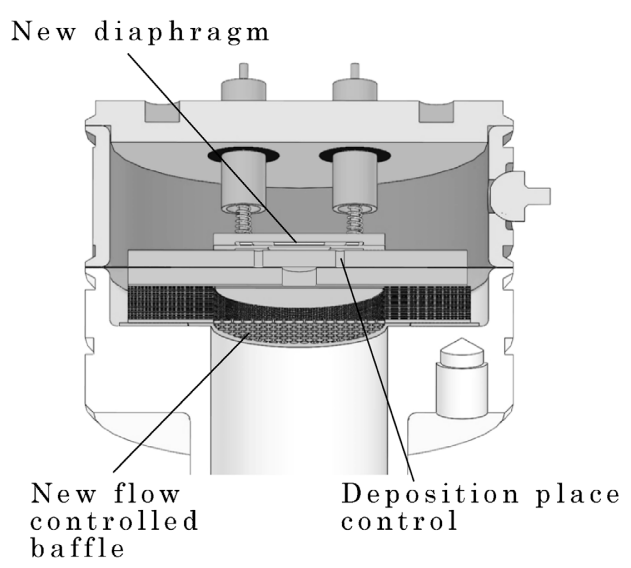

Fig. 8 Cross section of ALD model package.

\section{4. 原子層堆積法向けモデル}

近年，LSI の高集積化などに伴い半導体製造プロセスにお いて, 膜厚制御性や段差被覆性などに優れる原子層堆積法 (Atomic Layer Deposition：ALD）が注目されている。この 成膜プロセスでは, 被覆性に優れる反面, プロセス圧力の計 測に用いられる隔膜真空計内部にも成膜され, センサ出力が シフトしてしまうという問題がある，当社ではこのような課 題を解決すべく, 三つの技術的工夫を積み重ねたセンサ構造 を設計し，ALD 成膜プロセスに適用してもシフトが大幅に 低減できるモデルを開発した ${ }^{4,5)}$.

Fig. 8 にパッケージ構造の模式断面図を示す.

\section{1 ダイアフラム形状の改良}

膜が堆積された状態でもダイアフラムの撓み量が変化しな
いように，ダイアフラムの中央部分をわずかに薄くし，薄い 部分と厚い部分の撓みを相殺させる構造を形成した。この構 造により均一に成膜された場合のゼロ点のずれを低減してい る。

\section{2 堆積場所のコントロール}

成膜材料によってはダイアフラム上に膜が均一に堆積せ ず，ダイアフラム形状を工夫しても撓みが不均一となり，ゼ ロ点のずれが抑えられない場合がある．この課題解決のため にダイアフラムを覆うサファイア円板に膜応力によるダイア フラムの撓みがバランスしやすい場所へ成膜されるような流 路を形成した。この構造により不均一に成膜された場合でも ゼロ点のずれを低減している.

\section{3 流路の制限}

ダイアフラム形状の改良や堆積場所のコントロールの対策 を実施してもダイアフラム上に不要な膜が堆積することに変 わりはない，そのことにより長期的には測定感度や測定精度 が低下してしまう。そのため流路を微細にしてガスの流れを 粘性流ではなく分子流にすることにより，活性なガスを壁に ぶつかりやすくして消滅させ，不活性なガスのみが感圧ダイ アフラムまで到達できるようにするバッフル構造を開発し た．希薄流体シミュレーションにより反応性ガスが活性度を 保ったままこのバッフル構造を通過できる確率は約 $0.03 \%$ で あり, 通過できるガスはほぼ不活性ガスのみとなることが確 認できた。 またこのトラップ構造は 4000 本もの微細な通り 道を設けたもので，応答性への影響も最小限にした。

\section{5. おわりに}

極めて耐食性が高く機械的特性に優れた人工サファイアを 使用し, 最新のマイクロマシニング製造技術ならびに電子回 路技術を適用することにより，高精度，高安定，高耐食性の サファイア隔膜真空計を製品化できた. 現在,より低圧力レ ンジの製品や工業用高速通信規格に対応した製品を開発中で ある、今後はさらに高いユーザー価值を提供するため, より 良い製品を開発していきたい。

\section{〔文献〕}

1) Y. Yoshikawa, H. Harada, J. Ichihara, M. Nagata and T. Yamaguchi: azbil Technical Review, 52 (2011) 34.

2) M. Soeda, T. Kataoka, Y. Ishikura, S. Kimura, T. Masuda, Y. Yoshikawa and M. Nagata: IEEE Sensors, Florida, 2002, 1-II, 950.

3) M. Sekine, T. Ishihara, N. Sashinami and T. Tani: azbil Technical Review, 52 (2011) 28.

4) T. Ishihara, M. Sekine and T. Tochigi: azbil Technical Review, 55 (2014) 62.

5) T. Ishihara, T. Tochigi, J. Yoshinaga and Y. Yoshikawa: JSAP Autumn Meeting, Sapporo, 2014, 75th, 01-115. 